\title{
DAMPAK PERUBAHAN HARGA BAHAN BAKAR MINYAK (BBM) TERHADAP NILAI TUKAR PETANI (NTP) DI PROVINSI SULAWESI UTARA
}

\author{
Muhammad R. Ipango \\ Eyverson Ruauw \\ Nootje M. Benu
}

\begin{abstract}
ABSRACT
This study aims to determine the impact of changes in increasing fuel price on Farmers Exchange Rate (NTP) in North Sulawesi Province. This study uses secondary data, mainly from the Central Bureau of Statistics (BPS) of North Sulawesi. Data collection was conducted for four months, from December 2016 until April 2017. The data used in this research is data from 2013 until 2016. The research method used in this research is descriptive research. The results showed that with the increase of Fuel Oil price is one of the factors that influence the Farmer's Farmer's Exchange Rate (NTP) as a whole by increasing the cost of household consumption, agricultural production cost, transportation cost, and transportation cost
\end{abstract}

Keywords: Impact of change, Fuel price, the farmer exchange value (FEV), North Sulawesi

\begin{abstract}
ABSTRAK
Penelitian ini bertujuan untuk mengetahui dampak perubahan kenaikan BBM terhadap Nilai Tukar Petani (NTP) di Provinsi Sulawesi Utara. Penelitian ini menggunakan data sekunder terutama berasal dari Badan Pusat Statistik (BPS) Sulawesi Utara. Pengumpulan data dilakukan selama empat bulan, sejak bulan Desember 2016 sampai dengan April 2017. Data yang digunakan dalam penelitian ini yaitu data dari tahun 2013 sampai dengan tahun 2016.. Metode penelitian yang digunakan dalam penelitian ini adalah penelitian deskriptif. Hasil penelitian menunjukkan bahwa dengan naiknya harga Bahan Bakar Minyak (BBM) merupakan salah satu faktor yang mempengaruhi Nilai Tukar Petani (NTP) secara keseluruhan yaitu dengan meningkatnya biaya konsumsi rumah tangga, biaya produksi hasil pertanian, biaya transportasi, dan biaya pengangkutan.
\end{abstract}

Kata kunci: Dampak Perubahan, Harga Bahan Bakar Minyak (BBM), Nilai Tukar Petani (NTP), Sulawesi Utara 


\section{PENDAHULUAN}

\section{Latar Belakang}

Pertanian merupakan sektor yang penting dalam perekonomian Indonesia karena pertanian merupakan sektor yang memiliki cakupan yang kompleks dan luas, termasuk sector perikanan, kehutanan dan peternakan. Oleh sebab itu filosofi pembanguan pertanian harus dipahami dengan benar oleh setiap pihak yang terkait. Sektor pertanian tentu tidak dapat di pisahkan dengan sector-sektor pembangunan lain yang secara langsung dan tidak langsung mempengaruhi ekonomi Indonesia. Sembel (2012). Kebijakan yang diterapkan pemerintah dengan menaikan harga Bahan Bakar Minyak (BBM) yang pada awal bulan april 2001 dan kenaikan bertahap pada tahun-tahun berikutnya, berdampak pada sektor pertanian baik secara langsung maupun tak langsung. Dampak langsung terjadi pada harga sarana produksi pertanian seperti solar yang digunakan sebagai bahan bakar mesin produksi hasil pertanian. Dampak tak langsung terjadi pada biaya pengangkutan saprodi serta hasil pertanian, dimna alat pengangkutan menggunakan BBM yang harganya mengalami kenaikan harga BBM akan mempengaruhi harga-harga kebutuhan lain termasuk sarana produksi pertanian. Hal ini menyebabkan kenaikan biaya produksi usahatani, sehingga berpengaruh terhadap pendapatan usahatani (Mubarok, 2003).

Kenaikan harga BBM pada saat bersamaan semakin menambah beban masyarakat yang sampai saat ini masih juga menanggung beban krisis ekonomi. Kenaikan harga BBM yang terjadi semenjak tahun 2001 telah mengakibatkan efek domino masyarakat, baik secara ekonomi maupun sesial politik. Secara ekonomi, kenaikan tersebut mengakibatkan kenaikan harga-harga barang dan jasa (inflasi), bahkan kenaikan tersebut bias tak terkendali menyusul kenaikan BBM itu (Mubarok, 2003). Sektor pertanian merupakan salah satu sector atau lapangan usaha pendukung perekonomian Indonesia. Pada tahun 2004 sektor pertanian telah memberikan kontribusi besar 13,10 persen terhadap total PDB Indonesia dan menempati peringkat ketiga setelah sektor industry pengolahan dan sektor perdagangan, hotel, dan restoran. Dalam pembangunan nasional peranan sektor pertanian antara lain sebagai penyedia kebutuhan pangan pokok, pembentuk devisa (melalui ekspor), dan penampung tenaga kerja khususnya di daerah pedesaan. Mengingat bahwa dua pertiga penduduk Indonesia tinggal di daerah pedesaan dan sebagian besar masih menggantungkan hidupnya pada sektor pertanian ini, maka sangat diharapkan sector pertanian ini dapat merupakan motor penggerak pertumbuhan yang mampu meningkatkan pendapatan para petani ini dapat merupakan motor penggerak pertumbuhan yang mampu memengentaskan kemiskinan. Dengan orientasi pembangunan pertanian ke arah perbaikan kesejahteraan petani, maka sangat relevan untuk mengkaji nilai tukar petani (NTP) sebagai salah satu indikator tingkat kesejahteraan petani dan keadaan perekonomian pedesaan serta usahausaha perbaikan NTP ( Mashyuri, 2007 ).

Provinsi Sulawesi utara memiliki banyak sumber daya alam yang cukup potensial dari sector pertanian. Hal ini dapat dilihat dari kontribusi sector pertanian yang cukup besar terhadap kontribusi PDRB dan lebih dari 52\% rumah tangga di Sulawesi utara memiliki mata pencarian di sector pertanian. Untuk itu diperlukan pembangunan dan pengelolaan yang baik di sector ini guna meningkatkan produksi hasil pertanian sehingga tidak hanya dapat meningkatkan produksi hasil pertanian tetapi juga meningkatkan pendapatan daerah yang dapat di ukur melalui Nilai Tukat Petani (NTP). (Badan Pusat Statistik, 2012) Dalam pengukuran Nilai Tukar Petani (NTP) dipengaruhi oleh beberapa aspek,salah satunya harga BBM yang selalu terjadi fluktuasi. Untuk itu dalam penelitian ini bermaksud membahas dampak kenaikan BBM terhadap Nilai Tukar Petani di Sulawesi Utara.

\section{Perumusan Masalah}

Berdasarkan latar belakang diatas, rumusan masalah dalam penelitian ini adalah bagaimana dampak kenaikan BBM terhadap Nilai Tukar Petani di Sulawesi Utara tahun 2008 - 2015. 


\section{Tujuan Penelitian}

Untuk mengetahui dampak kenaikan BBM terhadap Nilai Tukar Petani ( NTP )

\section{Manfaat Penelitian}

a. Agar pembaca dapat mengetahui dampak yang terjadi karena kenaikan BBM terhadap Nilai Tukar Petani ( NTP)

b. Agar pembaca dapat mengetahui bagaimana perkembangan NTP dari sebelum kenaikan BBM sampai dengan saat ini.

\section{METODOLOGI PENELITIAN}

\section{Lokasi dan Waktu Penelitian}

Penelitian mulai dari persiapan sampai penyusunan laporan hasil penelitian dilaksanakan selama 4 bulan yaitu sejak bulan desember sampai april 2017, penelitian ini dilaksanakan di Badan Pusat Statistik Provinsi Sulawesi Utara.

\section{Metode Pengambilan Data}

Data yang digunakan dalam penelitian ini yaitu data time series dari tahun 2013 yang merupakan data sekunder, yang diambil dari instansi terkait dengan penelitian ini, yaitu di propinsi Sulawesi Utara yaitu Badan Pusat Statistik dan sumber-sumber relevan lainnya.

\section{Konsep Pengukuran variabel}

Variabel yang diukur dalam penelitian ini teridiri dari variabel indekks harga pada NTP. Indeks harga pada NTP terdiri dari It dan Ib.

a. indeks harga yang diterima petani ( It ) .indeks harga yang menunjukan perkembangan harga produsen atas hasil produksi petani.

b. Indeks harga yang dibayar petani ( $\mathrm{Ib}$ ). Indeks harga yang menunjukan perkembangan harga kebutuhan rumah tangga petani, baik kebutuhan untuk konsumsi rumah tangga maupun kebutuhan untuk proses produksi pertanian.

c. NTP. Merupakan salah satu indicator yang biasa digunakan untuk menilai tingkat kesejahtraan petani di pedesaan pada tahun tertentu dibandingkan dengan kondisi pada tahun dasar.

\section{Metode Pengelolaan Data}

Metode penelitian yang digunakan dalam penelitian ini adalah penelitian deskriptif. Metode penilitian deskriptif dimana penulis mengumpulkan data-data penelitian yang diperoleh dari objek penilitian dan literaturliteratur lainnya kemudian menguraikan secara rinci untuk mengetahui permasalahan penelitian dan mencari penyelesaiannya. Penelitian deeskriptif ini biasanya dilakukan dengan tujuan utama yakni berusaha untuk menggambarkan secara sistematis fakta atau bias juga karakteristik objek maupun subjek yang diteli (Sugiyono, 2004)

\section{HASIL DAN PEMBAHASAN}

\section{Deskripsi Lokasi Penelitian}

Provinsi Sulawesi Utara terletak di jazirah utara Pulau Sulawesi dan merupakan satu dari tiga provinsi di Indonesia yang memiliki keunggulan geoposisi, geostrategi, dan geopolitik serta terletak di tepian pasifik. Dua provinsi lainnya adalah Sumatera Utara dan Daerah Istimewa Aceh. Dilihat dari letak geografis Sulawesi Utara terletak pada 0.304.30 Lintang Utara (Lu) dan 121-127 Bujur Timur (BT). Kedudukan jazirah membujur dari timur ke barat dengan daerah paling utara adalah Kepulauan Sangihe dan Talaud. Wilayah kepulauan ini berbatasan langsung negara Tetangga Filipina. Wilayah Sulawesi Utara mempunyai batas-batas:

- Utara : Laut Sulawesi, Samudera Pasifik, dan Filipina

- Timur : Laut Mauluku

- Selatan : Teluk Tomini

- Barat : Provinsi Gorontalo

\section{Gunung di Sulawesi Utara}

Sebagian besar wilayah daratan Provinsi Sulawesi Utara terdiri dari pegunungan dan 
bukit-bukit diselingi oleh lembah yang membentuk daratan. Gunung-gunung terletak berantai dengan ketinggian di atas 1.000 dari permukaan laut. Beberapa gunung yang terdapat di Sulut yaitu Gunung Klabat (1.895 m) di Minahasa Utara, Gunung Lokon (1.579 $\mathrm{m})$, Gunung Mahawu (1.331 m) di Tomohon, Gunung Soputan $(1.789 \mathrm{~m})$ di Minahasa Tenggara, Gunung Dua Saudara (1.468 m) di Bitung, Gunung Awu (1.784), Gunung Ruang $(1.245 \mathrm{~m})$, Gunung Karangketang $(1.320 \mathrm{~m})$, Gunung Dalage $(1.165 \mathrm{~m})$, di Sangihe dan Talaud, Gunung Ambang (1.689 m), Gunung Gambula $(1.954 \mathrm{~m})$ dan Gunung Batu Balawan (1.970 m).

\section{Dataran Rendah dan Daratan Tinggi}

Dataran rendah dan dataran tinggi secara potensial mempunyai nilai ekonomi bagi daerah. Beberapa dataran terdapat di daerah ini adalah: Tondano (2.850 ha), Langowan (2.381 ha), Modoinding (2.350 ha), di Minahasa, Tompaso Baru (2.587 ha), di Minahasa Selatan, Tarun (265 ha) di Sangihe, Dumoga (21.100 ha), Ayong (2.700 ha), Sangkub (6.575 ha), Tungoi (8.020 ha), Poigar (2.440 ha), Molibagu (3.260 ha), Bintauna (6.300 ha) di Bolmong dan Bolmut.

\section{Danau dan Sungai}

Danau-danau di daerah ini secara potensial mempunyai nilai ekonomi bagi pengembangan bidang kepariwisataan, pengairan dan energi. Danau-danau tersebut adalah Danau Tondano dengan luas 4.278 ha di Minahasa, Danau Moat seluas 617 ha di Bolaang Mongondow Timur. Pada umumnya sungai-sungai dimanfaatkan untuk berbagai keperluan antara lain untuk irigasi juga sebagai sumber tenaga listrik dan sumber air minum. Sungai-sungai tersebut yakni Sungai Tondano (40 km), Sungai Poigar (54,2 km), Sungai Ranoyapo (51,9 km), Sungai Talawaan $(34,8 \mathrm{~km})$ di Minahasa. Sungai besar lainnya terdapat di Bolmong dan Bolmut yaitu Sungai Dumoga $(87,2 \mathrm{~km})$,
Sungai Sangkub (53,6 km), Sungkai Ongkaw $(42,1 \mathrm{~km})$.

\section{Struktur Tanah}

Struktur tanah di Sulut berupa Latosol seluas 531.000 ha tersebar di beberapa wilayah antara lain: Tagulandang, Tamako, Manganitu, Kendahe, Tabukan Utara, Esang, Pineleng, Tomohon, Tombariri, Airmadidi, Kakas, Eris, Kombi, Tareran, Passi, Modayag, Pinolosian dan Bolaang. Struktur tanah aluvial seluas 75.000 ha tersebar di beberapa wilayah antara lain: Tabukan Tengah, Lirung, Likupang, Wori, Tombasian, Tenga, Tompaso Baru, Belang dan Tondano. Itulah gambaran kondisi Geografi Sulawesi Utara, sebuah provinsi yang berada di paling utara pulau Sulawesi yang dikaruniai dengan keindahan alam yang sungguh mengagumkan.

\section{Perubahan harga BBM}

Tabel 1. Pergerakan harga bahan bakar minyak (BBM )

\begin{tabular}{llccl}
\hline Berlaku & & \multicolumn{3}{c}{ Harga Bahan Bakar Minyak } \\
\hline Tahun & Tanggal & Premium & Solar & $\begin{array}{l}\text { Minyak } \\
\text { Tanah }\end{array}$ \\
\hline 2016 & 1 April & 6.450 & 5.150 & 2.500 \\
& 5 Januari & 6.950 & 5.650 & 2.500 \\
2015 & 28 Maret & 7.300 & 6.900 & 2.500 \\
& 1 Maret & 6.800 & 6.400 & 2.500 \\
& 19 Januari & 6.700 & 6.400 & 2.500 \\
& 1 Januari & 7.600 & 7.250 & 2.500 \\
2014 & 18 & 8.500 & 7.500 & 2.500 \\
2013 & November & 6.500 & 5.500 & 2.500 \\
& 22 Juni & & & \\
\hline
\end{tabular}

Tabel 1 menunjukan bahwa pergerakan naiknya BBM dimulai 22 juni 2013 premium 6.500 ,solar 5.500 , dan kembali naik 18 november 2014 dengan kenaikan masing masing premium dan solar naik 2.000. pada awal tahun 2015 terjadi penurunan harga BBM yaitu pada tanggal 1 dan 19 januari dan kembali naik di bulan maret yaitu tanggal 1 dan 28 maret. Dengan premium 7.300 dan solar 6.900. dan pada tahun berikut harga kembali turun di bulan januari dan april hingga sekarang ini. 
Dampak Kenaikan BBM Tahun 201

Ntp Sebelum Naik Bbm

Tabel 2. NTP, It dan Ib Bulan Januari-Juni tahun 2013

\begin{tabular}{llll}
\hline Bulan & NTP & It & Ib \\
\hline Januari & 100.83 & 139.26 & 138.11 \\
February & 100.84 & 139.50 & 138.33 \\
Maret & 101.11 & 140.22 & 138.68 \\
April & 101.05 & 140.82 & 139.37 \\
Mei & 101.56 & 141.74 & 139.57 \\
Juni & 101.84 & 141.85 & 139.30
\end{tabular}

Sumber : Badan Pusat Statistik Sulawesi Utara 2013

Pada awal tahun 2013 sampai pada bu-lan Juli, NTP (Nilai Tukar Petani) Provinsi Su-lawesi Utara setiap bulannya sempat berada pada angka di atas 100. Artinya, selama bulan Januari hingga Juli di tahun 2013 umumnya petani di Sulawesi Utara mempunyai ke-hidupan yang lebih sejahtera.

\section{NTP SESUDAH NAIK BBM}

Tabel 3. NTP, It dan Ib Juli-Desember tahun 2013

\begin{tabular}{llll}
\hline Bulan & NTP & It & Ib \\
\hline Juli & 101.53 & 145.09 & 142.89 \\
Agustus & 99.93 & 145.03 & 145.13 \\
September & 98.96 & 144.06 & 145.57 \\
Oktober & 99.20 & 143.97 & 145.13 \\
November & 99.46 & 145.16 & 145.94 \\
Desember & 99.68 & 146.22 & 146.69
\end{tabular}

Sumber : Badan Pusat Statistik Sulawesi Utara 2013

Peningkatan $\mathrm{Ib}$ terbesar di sepanjang ta-hun 2013 berada di bulan Juli sebesar 2.58 persen dan penurunan terbesar di bulan Oktober sebesar 0.30 persen. Fluktuasi nilai-nilai tersebut disebabkan oleh perubahan yang terjadi pada harga konsumsi rumah tangga dan BPPBM yang dikeluarkan oleh petani.

\section{Dampak Kenaikan BBM Tahun 2014}

\section{Ntp Sebelum Naik Bbm 2014}

Tabel 4. NTP, It dan Ib Bulan Juni-Oktober tahun 2014

\begin{tabular}{lcll}
\hline Bulan & NTP & It & Ib \\
\hline Juni & 99.99 & 111.50 & 111.51 \\
Juli & 99.73 & 111.92 & 112.22 \\
Agustus & 99.75 & 111.56 & 111.84 \\
September & 99.87 & 112.01 & 112.16 \\
Oktober & 99.51 & 112.46 & 113.02 \\
\hline
\end{tabular}

Sumber : Badan Pusat Statistik Sulawesi Utara 2014

Tabel 4 menunjukan bahwa NTP bulan Juni dan Juli mengalami penurunan dari 99.99 menjadi 99.99 turun 0.23 . pada bulan agustus dan September mengalami sedikit peningkatan menjadi 99.75 dan 99.87, dan di bulan oktober kembali mengalami penurunan menjadi 99.51 .

\section{Ntp Sesudah Naik Bbm 2014}

Tabel 5. NTP, It dan Ib Bulan NovemberDesember tahun 2014

\begin{tabular}{|c|c|c|c|}
\hline Bulan & NTP & It & $\mathrm{Ib}$ \\
\hline November & 99.62 & 114.01 & 114.45 \\
\hline Desember & 97.52 & 114.55 & 117.66 \\
\hline
\end{tabular}

Tabel 5 menunjukan bahwa Indeks $\mathrm{Ib}$ terbesar di sepanjang tahun 2014 berada di bulan Desember sebesar 117,66. Pergerakan perubahan indeks ini lebih disebabkan pada pergerakan indeks harga konsumsi rumah tangga dan Biaya Produksi dan Penambahan Barang Modal (BPPBM) yang dikeluarkan oleh petani.

Dampak Kenaikan Bbm Tahun 2015

Ntp Sebelum Naik Bbm 2015

Tabel 6. NTP, It dan Ib Bulan Januari-Bebruari 2015

\begin{tabular}{llll}
\hline Bulan & NTP & It & Ib \\
\hline Januari & 98.04 & 114.66 & 116.94 \\
february & 98.51 & 115.17 & 116.91 \\
\hline \multicolumn{2}{l}{ Sumber : Badan Pusat Statistik Sulawesi } & Utara 2015
\end{tabular}




\section{Ntp Sesudah Naik Bbm 2015}

Tabel 7. NTP , It dan Ib Bulan Maret - Juli tahun 2015

\begin{tabular}{llll}
\hline Bulan & NTP & It & Ib \\
Maret & 97.49 & 114.64 & 117.60 \\
April & 96.55 & 113.20 & 117.24 \\
Mei & 95.79 & 112.68 & 117.63 \\
Juni & 94.70 & 112.34 & 118.64 \\
Juli & 95.42 & 113.68 & 119.14
\end{tabular}

Sumber : Badan Pusat Statistik Sulawesi Utara 2015

Tabel 7 menunjukan bahwa NTP tahun 2015 di mulai dari angka di bawah 100 yaitu 98.04 di bulan januaridan di bulan februari mengalami sedikit peningkatan 0.47 yaitu 98.51 dengan It di bulan januari 114.66 dan di bulan February 115.17 mengalami sedikit peningkatan. Di awal tahun juga Ib mengalami penurunan 0.3 yaitu di bulan januari 116.94 dan di bulan februari 116.91. Dari data di atas Penurunan nilai tukar petani disebabkan peningkatan harga-harga komoditi hasil pertanian yang diusahakan petani tidak dapat melampaui harga-harga komoditi yang dibutuhkan oleh petani untuk konsumsi rumah tangganya dan biaya produksi dan penambahan barang modal di pertanian. Hal ini terlihat dari pergerakan indeks yang diterima petani, yang bersumber dari harga produk pertanian yang dihasilkan (It), bergerak di bawah pergerakan indeks yang dibayarkan petani, yang bersumber dari harga komoditi pengeluaran rumah tangga petani dan biaya produksi dan penambahan barang modal petani (Ib). Dikarenakan di tahun 2016 tidak mengalami kenaikan BBM dan hanya mengalami penurunan maka yang akan dilihat disini pengaruh penurunan BBM di tahun 2016. NTP Provinsi Sulawesi Utara di sepan-jang tahun 2016 setiap bulannya selalu be-rada di bawah angka 100, artinya bahwa sela-ma bulan Januari hingga Desember tahun 2016 umumnya petani di Sulawesi Utara mempunyai kehidupan yang kurang baik, Dengan kata lain petani di Sulawesi Utara di tahun 2016 memiliki kemampuan daya beli yang kurang lebih baik. Penurunan nilai tukar petani disebab-kan peningkatan harga-harga komoditi hasil pertanian yang diusahakan petani tidak dapat melampaui harga-harga komoditi yang dibutuhkan oleh petani untuk konsumsi rumah tangganya dan biaya produksi dan penamba-han barang modal di pertanian. Nilai Tukar Petani di sepanjang tahun 2016 cenderung menunjukkan pergerakan yang lambat dan selalu berada di bawah seratus. Kondisi ini seharusnya perlu mendapat perhatian oleh pemerintah daerah dan instansi terkait, khususnya dalam peningkatan kesejahteraan petani.

Tabel 6. NTP, It dan Ib Bulan JanuariDesember tahun 2016

\begin{tabular}{llll}
\hline Bulan & NTP & It & Ib \\
\hline Januari & 97.69 & 120.26 & 123.11 \\
Februari & 97.47 & 119.83 & 122.94 \\
Maret & 96.83 & 119.53 & 123.44 \\
April & 97.14 & 119.38 & 122.90 \\
Mei & 96.63 & 118.78 & 122.92 \\
Juni & 97.00 & 119.76 & 123.46 \\
Juli & 97.00 & 119.78 & 123.58 \\
Agustus & 96.93 & 119.39 & 124.15 \\
September & 95.82 & 118.73 & 123.90 \\
Oktober & 94.54 & 117.13 & 123.90 \\
November & 94.44 & 117.37 & 124.28 \\
Desember & $93 . .94$ & 116.61 & 123.14 \\
\hline Sumber : Bactan & Pusat Statistik Sulawesi
\end{tabular}

Sumber : Badan Pusat Statistik Sulawesi Utara 2016

Tabel 6 menunjukan bahwa ini terlihat dari pergerakan indeks yang diterima petani, yang bersumber dari harga produk pertanian yang dihasilkan (It), bergerak di bawah pergerakan indeks yang dibayarkan petani, yang bersumber dari harga komoditi pengeluaran rumah tangga petani dan biaya produksi dan penambahan barang modal petani (Ib).

\section{KESIMPULAN DAN SARAN}

\section{Kesimpulan}

Dari hasil penelitian dan pembahasan di atas, maka dapat ditarik kesimpulan bahwa dampak dari kenaikan BBM terhadap Nilai Tukar Petani ( NTP ) bahwa dengan naiknya BBM mempengaruhi NTP dikarenakan meningkatnya barang yang digunakan untuk memproduksi hasil pertanian, meningkatkan 
biaya konsumsi rumah tangga petani, biaya tranportasi, pengangkutan, biaya produksi dan penambahan barang modal (BPPBM). Dan dengan menurunnya harga BBM belum juga terlalu mempengaruhi naiknya NTP, dikarenakan untuk peningkatan harga - harga komoditi hasil pertanian yang diusahakan petani tidak dapat melampaui harga - harga komoditi yang dibutuhkan oleh petani untuk konsumsi rumah tangganya, biaya produksi dan penambahan barang modal. Kondisi ini seharusnya perlu mendapat perhatian oleh pemerintah daerah dan instansi terkait, khususnya dalam peningkatan kesejahteraan petani.

\section{Saran}

Berdasarkan hasil penelitian maka saran yang dapat saya berikan yaitu untuk meningkatkan kesejahtraan petani berarti harus meningkatkan nilai tukar petani. NTP terdiri dari nilai yang diterima dan nilai yang dibayarkan petani. Untuk meningkatkan nilai tukar petani maka petani harus meningkatkan nilai produksi pertanian dan mengurangi nilai konsumsi rumah tangga (KRT) dan biaya produksi dan penambahan barang modal (BPPBM). Dan Jika terjadi kenaikan harga BBM maka sebaiknya pemerintah lebih memperhatikan petani. Dikarenakan pemerintah juga harus mengimbangi dengan menaikan harga-harga komoditi hasil pertanian yang diusahakan petani, dan meminimalisir kenaikan harga barang yang di butuhkan petani untuk konsumsi rumah tangganya sehingga petani bisa mengalami kesejahtraan.

\section{DAFTAR PUSTAKA}

Badan pusat statistik, 2006. Statistik Nilai Tukar Petani di Indonesia (Pangan dan Perkebunan Rakyat. Badan Pusat statistik. Manado.

BPS. 1980-2016. Statistik Indonesia. Jakarta.

BPS. 2010. Statistik Nilai Tukar Petani di Indonesia.
Dillon HS, M Husein Sawit, Pantjar S, Tabor S.T.1999. Rice Policy: A Framework for The Next Millenium, Report for Internal Review Only Prepared Under Contract to BULOG.

Hernanto F., 1991. Ilmu Usahatani. Penebar Swadaya. Jakarta. Karmiati, 2007. Nilai Tukar Petani Secara Nasional Naik 7,14 Persen

Kasryno, Faisal. 2012. Pelaksanaan MP3EI Koridor Jawa Akan Menyebabkan Ketahanan Pangan Nasional Semakin Parah. Makalah Dalam Buku Kemandirian Pangan Indonesia Dalam Perspektif MP3EI. Badan Penelitiian Dan Pengembangan Pertanian. Kementerian Pertanian. 2012.

Khan, Abdul Aleem and Q. M. Ahmed. 2004. Agricultural Terms of Trade in Pakistan: Issues of Profitability and Standar of Living of the Farmers. The Pakistan Development review. Vol. 43 (4): 515-537.

Masyhuri. 2007. Revitalisasi Pertanian Untuk Mensejahterakan Petani. Makalah pada Konpernas XV dan Kongres XIV PERHEPI, Surakarta, 3-5 Agustus 2007.

Nugraha, et al, 1998. Solusi Kumuh Net Untuk Wong-Cilik (Cara-cara Membuat Nilai Tukar Petani Tinggi).

Pusat Data dan Informasi Pertanian, 2004. Buletin Nilai Tukar Petani. http://www.deptan.go.id/buletin/ntp05/ nt p05/buletin-ntp1-05.pdf

Sembel, 2012. Dasar-dasar perlindungan tanaman.Andi, Yogyakarta.

Setiani, et al, 2007. Kontribusi Teknologi Usahatani dan Aprestasi Pasar Terhadap Nilai Tukar Petani Di Wilayah Miskin. 
Soekartawi. 2003. Teori Ekonomi Produksi. PT. Raja Grafindo Persada. Jakarta.

Statistik, 2006. Perkembangan Nilai Tukar Petani, Harga Produsen Gabah dan Upah buru.

Supriyati, Muchjidin Rachmat, Kurnia Suci I., Tjetjep Nurasa, R. E. Manurung dan Rosmiyati S. 2000. Studi Nilai Tukar Petani dan Nilai Tukar Komoditas Pertanian. Laporan Hasil Penelitian. Pusat Penelitian Sosial Ekonomi Pertanian. Departemen Pertanian. Bogor.

Tambunan. 2003. Perkembangan Sektor Pertanian Di Indonesia (Beberapa Isu Penting), Penerbit Ghalia, Jakarta
Tambunan, 2006. Apakah Pertumbuhan di Sektor Pertanian Sangat Krusial Bagi Pengentasan Kemiskinan di Indonesia.

Winarno, J., 2002. Dampak kegiatan sub sektor pertanian tanaman pangan terhadap perekonomian kebupaten minahasa. Skripsi. Fakultas Pertanian Universitas Sam Ratulangi. Manado

Wulandari, W., 2015. Peranan Produk Domestik Regional Bruto Sub-Sektor Perkebunan Terhadapa Pertumbuhan Ekonomi Di Kabupaten Bolaang Mongondow. Skripsi. akultas Pertanian Universitas Sam Ratulangi. Manado 